\title{
IMPLEMENTASI METODE BUBLE SORT PADA RANCANG BANGUN APLIKASI PENCARIAN RUTE BERDASARKAN JARAK TEMPUH ANGKUTAN UMUM WILAYAH KABUPATEN KARANGANYAR BERBASIS ANDROID (KRAWIS ANGKOT - KARANGANYAR WISATA ANGKUTAN UMUM)
}

\author{
Silviana Wahyu Dwitasari, , Meilia Nur Indah Susanti, Herman Bedi Agtriadi \\ Teknik Informatika, STT-PLN Jakarta
}

\begin{abstract}
Abstrak
Perkembangan teknologi yang sangat cepat membawa pengguna teknologi untuk hidup dengan tak lepas dari teknologi informasi itu sendiri. Melalui teknologi informasi yang berkembang saat ini, pengelolaan informasi dapat dilakukan dengan lebih efektif dan efisien. Dalam hal ini, penulis ingin berpartisipasi dalam pengembangan teknologi informasi lokasi dalam bentuk mobile yaitu aplikasi pencarian rute angkutan umum berbasis android yang mana aplikasi ini nantinya akan memberikan informasi rute angkutan umum dari satu lokasi wisata ke lokasi wisata lainnya. Aplikasi ini memberikan kemudahan kepada masyarakat sekitar dalam mencari informasi tentang angkutan umum sesuai kebutuhan yang berada di Kabupaten Karanganyar. Aplikasi ini juga akan menampilkan mengenai lokasi-lokasi wisata yang berada pada wilayah Kabupaten Karanganyar yang disertai dengan foto-foto lokasi wisata tersebut. Secara garis besar, aplikasi ini akan memberikan informasi lengkap mengenai rute angkutan menuju lokasi wisata Kabupaten Karanganyar serta tarif tiap angutan umum. Metode yang digunakan dalam pembuatan aplikasi ini adalah metode buble sort. Metode ini digunakan untuk mengurutkan pilihan rute angkutan umum berdasarkan jarak tempuh. Kesimpulan yang didapat adalah aplikasi ini mampu membantu masyarakat dalam menentukan rute angkutan umum menuju lokasi wisata dengan tepat.
\end{abstract}

Kata Kunci : Angkutan Umum, Wisata Karanganyar, Android

\begin{abstract}
The rapid technological development brings user to livewithout departing from the information technology itself. Through information technology at this time, information managemen can be done more efffectively and efficiently. In this case, the author would like to participte in the development of information technology in the form of mobile location, and it's transit rout android-based search application. Which this application will be giving the route of trasnpot information from one destination to other destination. This application alllows people around in search of information about the public transport according to the needs around the District of Karanganyar. This application will also display the tourist sites that are ocated at the District of Karanganyar incuding the photos of it. this app will provide full information regarding the transport route to the location Karanganyar district and each public transport fares. The method used in this application is the bubble sort method. This method is used to sort the order of selection of public transport based on mileage. the conclusion obtained is application is able to assist communities in determining the transit route to the right location.
\end{abstract}

Keywords : Public Transport Based, destination of Karanganyar, Android

\section{Pendahuluan}

Saat ini perkembangan teknologi berkembang pesat salah satunya adalah perkembangan teknologi mobile. Teknologi ini bukan hanya digunakan sebagai media komunikasi saja tetapi juga dapat digunakan sebagai media informasi yang efisien karena selain dapat dibawa kemanapun, teknologi ini juga menyediakan fitur-fitur yang dibutuhkan oleh pengguna.

Di era globalisasi ini pasti sudah tidak asing dengan kata travelling dan backpacker. Travelling mempunyai arti berpergian atau yang sering kita sebut dengan jalan-jalan. Sedangkan backpacker adalah berpergian atau jalan-jalan dengan kemauan sendiri dan dengan dana yang seringan mungkin. Tak sedikit yang menyukai kegiatan tersebut. Kegiatan travelling ini dapat meringankan otak yang penat akan suatu kegiatan atau pekerjaan. Akan tetapi tak sedikit pula yang berfikir dua kali untuk melakukan kegiatan tersebut (Triyudanto, 2012).

Faktor pertama adalah dana, karena jika akan travelling maka akan mengeluarkan dana yang tidak sedikit. Faktor kedua yang menghalangi keinginan pengguna untuk travelling adalah transportasi, jika akan membawa kendaraan sendiri selain nantinya menimbulkan kemacetan di jalan juga akan sedikit meguras tenaga pada perjalanan sedangkan jika ingin menaiki angkutan umum, pengguna tidak mengetahui rute-rute angkutan umum yang menuju tempat tujuan wisata. Faktor ketiga adalah tempat wisata. Dengan hanya berbekal minimum informasi yang pengguna dengar dari suatu berita ataupun hanya dari mulut ke mulut saja sehingga terkadang banyak yang kecewa karena tidak sesuai dengan apa yang pengguna bayangkan sebelumnya. Tempat wisata yang sebenarnya mengagumkan 
dapat terlewatkan karena minimnya informasi yang kita dapat.

Pada umumnya seorang backpacker melakukan perjalanan secara mandiri atau independent. Artinya, para backpackrer tersebut tidak mau menggunakan jasa agen perjalanan apalagi dengan biaya yang cukup besar. Karena tidak menggunakan jasa agen wisata, para backpacker selalu menggunakan transportasi umum yang biasa digunakan oleh penduduk lokal. Pada pembahasan kali ini, transportasi yang digunakan lebih mengarah pada transportasi angkutan umum berupa angkot trayek dan mini bus (bus 16 seat).

Dengan memanfaatkan teknologi Smartphone berbasis android yang sedang berkembang serta berdasarkan masalah yang telah disebutkan diatas, maka penulis mencoba menganalisis dan mengimplementasikan permasalahan tersebut dengan judul : IMPLEMENTASI METODE BUBLE SORT PADA RANCANG BANGUN APLIKASI PENCARIAN RUTE BERDASARKAN JARAK TEMPUH ANGKUTAN UMUM WILAYAH KABUPATEN KARANGANYAR BERBASIS ANDROID (KRAWIS ANGKOT - Karanganyar Wisata Angkutan Umum).

\section{Landasan Teori}

\subsection{Angkutan Umum}

Angkutan pada dasarnya adalah sarana untuk memindahkan orang dan atau barang dari satu tempat ke tempat lain. Tujuannya membantu orang atau kelompok orang menjangkau berbagai tempat yang dikehendaki atau mengirimkan barang dari tempat asalnya ke tempat tujuannya. Prosesnya dapat dilakukan dengan menggunakan sarana angkutan berupa kendaraan.

Sementara Angkutan Umum Penumpang adalah angkutan penumpang yang menggunakan kendaraan umum yang dilakukan dengan sistem sewa atau bayar. Termasuk dalam pengertian angkutan umum penumpang adalah angkutan kota (bus, minibus, angkot), kereta api, angkutan air, dan angkutan udara (Warpani, 1990).

Angkutan Umum Penumpang bersifat masal sehingga biaya angkut dapat dibebankan kepada lebih banyak orang atau penumpang yang menyebabkan biaya per penumpang dapat ditekan serendah mungkin. Karena merupakan angkutan masal, perlu ada kesamaan diantara para penumpang, antara lain kesamaan asal dan tujuan. Kesamaan ini dicapai dengan cara pengumpulan di terminal dan atau tempat perhentian.

Kesamaan tujuan tidak selalu berarti kesamaan maksud. Angkutan umum masal memiliki trayek dan jadwal keberangkatan yang tetap. Pelayanan angkutan umum penumpang akan berjalan dengan baik apabila tercipta keseimbangan antara ketersediaan dan permintaan (Warpani, 1990).

\subsection{Aplikasi}

Menurut KBBI (Kamus Besar Bahasa Indonesia), aplikasi adalah penggunaan, peneraan, lamaran. Secara istilah aplikasi adalah program siap pakai yang direka untuk melaksanakan suatu fungsi bagi pengguna atau aplikasi yang dan dapat digunakan oleh sasaran yang dituju.

\subsection{Android}

Android adalah sebuah system operasi untuk perangkat mobile berbasis linux yang mencakup system operasi, middleware dan aplikasi. Android menyediakan platform terbuka bagi para pengembang untuk menciptakan aplikasi pengguna sendiri. (Dodo, 2012).

\subsection{Android SDK(Software Development Kit)}

Android SDK adalah tools API (Application Programming Interface) yang diperlukan untuk mulai mengembangkan aplikasi pada platform Android menggunakan bahasa pemrograman Java.

Android merupakan subset perangkat lunak untuk ponsel yang meliputi sistem operasi, middleware dan aplikasi kunci yang di-release oleh Google. Saat ini disediakan Android SDK (Software Development Kit) sebagai alat bantu dan API untuk memulai mengembangkan aplikasi pada platform Android menggunakan bahasa pemrograman Java (Nazzrudin, 2013)

\subsection{Java Development Kit (JDK)}

Bahasa pemrograman Android menggunakan bahasa Java, maka dibutuhkan JDK Java Development Kit. JDK berguna saat kita menulis code program seperti halnya JRE (Java Runtime Environment), JDK juga mempunyai JVM (Java Virtual Manchine) di dalamnya. JDK terdiri dari lingkungan eksekusi program yang berada di atas Operating System, sebagaimana dibutuhkan oleh para programmer untuk meng-compile, membenahi bug(s) yang ada dan menjalankan tambahantambahan dari program intinya yang ditulis dengan menggunakan bahasa pemrograman Java.

Teknologi Java memiliki tiga komponen penting yaitu: programming-language spesification, application-programming interface dan virtualmanchine spesification. Sebuah JDK diperlukan untuk pengembangan fungsionalitas Java, tetapi tidak untuk pembangunan di bahasa pemrograman lain. JDK yang bisa digunakan untuk membuat program Android adalah JDK 5 dan JDK 6 atau versi terbarunya (Gumelar, 2015).

\subsection{Jquery Mobile}

JQuery mobile adalah sebuah library pengembangan aplikasi mobile berbaris web yang dikembangkan oleh jquery, tetapi spesifik untuk perangkat mobile. Sehingga tampilan $\mathrm{html}$ akan memiliki sense mobile (Webhozz, 2015).

\subsection{Phonegap}

Phonegap adalah suatu framework aplikasi yang memungkinkan anda untuk membangun aplikasi native android menggunakan HTML dan Javascript. Phonegap memudahkan untuk para developer pemula android untuk membangun suatu aplikasi. Phonegap juga memberikan kreasi dan tampilan yang sangat menarik karena dibuat dengan menggunakan perintah HTML dan Javasctipt. Selain itu phonegap dapat digunakan oleh semua macam operasi sistem seperti android, 
IOS, blackberry, windows phone, bada dan lain sebagainya.

Ketika mengembangkan aplikasi PhoneGap, developer hanya menjalankan kode dalam bentuk web browser. Developer mengembangkan aplikasi menggunakan HTML dan JavaScript, bukan menggunakan kode android aslinya, sehingga kita tidak perlu mempelajari bahasa baru serta sebagian besar pengembangannya di desktop menggunakan editor HTML dan browser Chrome. Dan menguji tampilan tersebut dengan menggunakan plugin dari browser Chrome (Luis, 2016).

\subsection{Buble Sort}

Bubble Sort adalah metode pencarian yang mengambil dari sifat gelembung yaitu mengampung artinya mengambil nilai paling besar dan di letakan dipaling kanan. Buble sort mengurutkan data dengan cara membandingkan elemen sekarang dan elemen berikutnya. Jika elemen sekarang lebih besar dari elemen berikutnya maka elemen tersebut ditukar (untuk pengurutan ascending). Jika elemen sekarang lebih kecil daripada elemen berikutnya, maka kedua elemen tersebut ditukar (untuk pengurutan descending).

\subsection{Metodologi Pengembangan Perangkat Lunak Multimedia Luther}

Metodologi pengembangan multimedia terdiri dari enam tahap, yaitu concept (pengkonsepan), design (pendesainan), material collecting (pengumpulan materi), assembly (pembuatan), testing (pengujian) dan distribution (pendistribusian). Keenam tahap ini tidak harus berurutan dalam praktiknya, tahap-tahap tersebut dapat saling bertukar posisi. Meskipun tahapnya dapat saling bertukar posisi, tetapi tahap pengkonsepan harus dikerjakan terlebih dahulu.

\section{Metodologi Penelitian}

\subsection{Kerangka Pemikiran}

Berdasarkan metodologi pengembangan perangkat lunak luther tersebut maka dibuatlah kerangka pemikiran sebagai berikut :

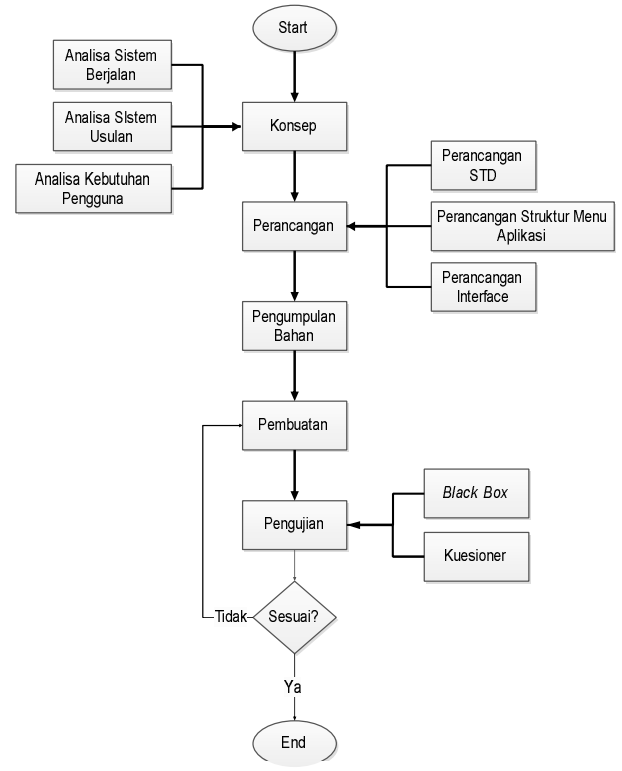

Gambar 2.1 Kerangka Pemikiran

\subsection{Analisis Sistem berjalan}

Berdasarkan hasil observasi yang dilakukan pada masyarakat wilayah Kabupaten Karanganyar, maka dilakukan analisis terhadap sistem yang sedang berjalan dalam proses menuju lokasi tempat wisata menggunakan angkutan umum.

Pertama, pengguna menentukan tujuan tempat wisata yang akan dikunjungi kemudian pengguna mencari informasi tujuan tempat wisata yang sudah ditentukan tersebut. Tahap selanjutnya adalah pengguna mencari informasi mengenai rute angkutan umum yang menuju lokasi tempat wisata tersebut. Informasi rute angkutan tersebut didapat dengan cara bertanya kepada masyarakat setempat atau dengan cara searching pada internet. Setelah mendapatkan semua informasi yang dibutuhkan, pengguna menaiki angkutan umum menuju tempat wisata yang diinginkan.

Berikut ini gambaran sistem yang berjalan pada masyarakat unntuk menentukan rute angkutan umum menuju lokasi wisata.

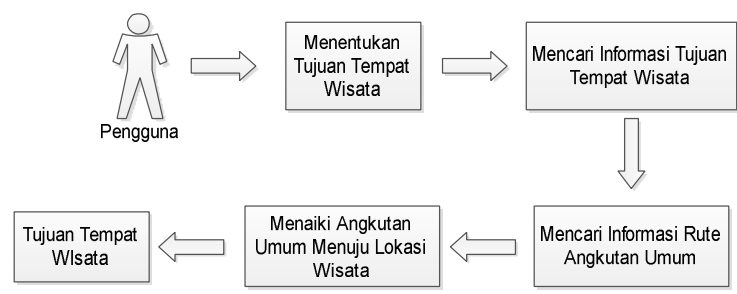

Gambar 3.1 Alur Sistem Berajalan Pencarian Rute ANGKUTAN UMUM

Dari analisis tersebut didapat kendala-kendala yang terjadi adalah sebagai berikut :

1. Resiko salah menaiki angkutan umum yang menuju lokasi wisata besar

2. Lokasi wisata tujuan tidak sesuai dengan apa yang diinginkan

3. Membutuhkan waktu cukup lama untuk mencari informasi rute angkutan umum teersebut

\subsection{Analisa Sistem Usulan}

Berdasarkan analisa sistem yang berjalan dan analisa kebutuhan sistem maka penulis mengusulkan aplikasi yang dapat membantu pengguna diantaranya adalah membuat aplikasi yang dapat menampilkan informasi mengenai tempat wisata wilayah Kabupaten Karanganyar. Penulis juga mengusulkan aplikasi pencarian rute angkutan umum dari lokasi wisata satu menuju lokasi wisata lainnya beserta tarif tiap trayek angkutan umum yang akan dinaiki.

Pada pembuatan aplikasi ini, penulis menggunakan metode buble sort untuk mengurutkan beberapa pilihan rute yang ada berdasarkan jarak yang ditempuh menuju lokasi tersebut sesuai dengan rute angkutan umum tersebut. Jarak tempuh yang dimaksud dalam aplikasi ini adalah total jarak tempuh dari lokasi wisata satu ke lokasi wisata yang lainnya berdasarkan rute angkutan umum sekaligus dengan jarak transit dari angkutan umum satu ke angkutan 
umum yang lainnya. Total jarak yang ditempuh tersebut kemudian dibandingkan sehingga menghasilkan rute angkutan umum terpendek berdasarkan jaraknya.

Aplikasi yang penulis usulkan ini dapat memberikan beberapa pilihan rute angkutan umum sehingga pengguna nantinya akan dapat memilih rute angkutan umum sesuai dengan pilihan masingmasing. Aplikasi yang akan dirancang bangun ini diharapkan akan dapat membantu dan user friendly bagi pengguna sehingga dapat diakses dengan baik. Berikut alur sistem usulah pencarian rute angkutan umum :

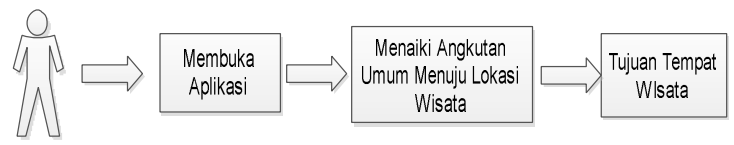

\section{Gambar 3. 2 alur Sistem Usulan Pencarian Rute} ANGKUTAN UMUM

Pada sistem pencarian rute angkutan umum yang penulis usulkan, pertama user harus membuka aplikasi, kemudian user dapat melihat informasi mengenai tempat wisata Kabupaten Karanganyar dan pengguna dapat menentukan lokasi yang akan dituju. Selanjutnya pengguna memilih lokasi awal dan lokasi tujuan wisata dan sistem akan melakukan proses pencarian rute angkutan umum sesuai dengan lokasi awal dan lokasi tujuan yang telah dipilih. Pada proses selanjutnya sistem akan menampilkan hasil pilihan rute angkutan umum yang sudah terurut berdasarkan jarak terpendek rute angkutan umum beserta tarif tiap trayek angkutan umum. Selanjutnya pengguna dapat memilih rute angkutan yang diinginkan.

Pada sistem ini, pengguna juga dapat melihat jalur rute angkutan umum yang dipilih melalui google map yang sudah ditandai menurut rute angkutan umum. Pada google map tersebut dapat menampilkan lokasi transit angkutan umum.

\subsection{Perancangan}

\subsubsection{Perancangan STD}

State Transition Diagram (STD) adalah suatu diagram yang menggambarkan bagaimana suatu proses dihubungkan satu sama lain dalam waktu bersamaan. Aplikasi yang akan dibuat penulis ini menggunakan rancangan STD sebagai berikut :

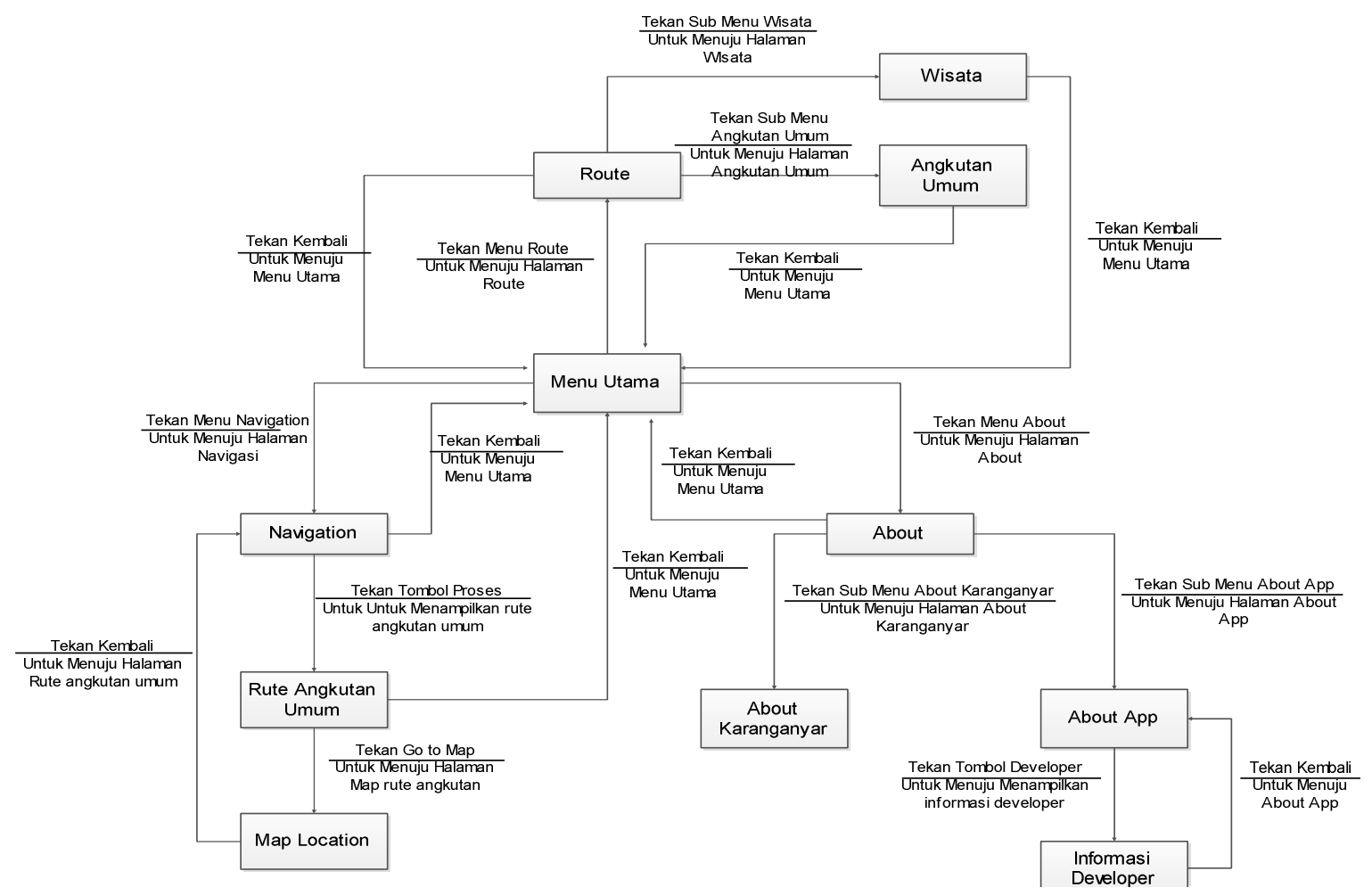

Gambar 3. 3 Perancangan State Transition Diagram (STD)

Aplikasi ini mempunya empat menu yaitu home sebagai menu utama, route sebagai media informasi trayek angkutan umum dan lokasi tempat wisata, navigation sebagai halaman navigasi yang digunakan untuk proses pencarian rute angkutan umum dan menu about sebagai media informasi mengenai Karanganyar dan aplikasi itu sendiri serta informasi mengenai penulis.

\subsubsection{Perancangan Interface}

Pada tahap ini penulis merancang tampilan yang akan di bangun pada aplikasi rute angkutan umum berbasis android tersebut.

\section{Rancangan Tampilan Home}

Halaman ini adalah halaman utama dari aplikasi pencarian rute angkutan umum tersebut. halaman ini terdiri dari empat menu diantaranya adalah Home, Route, Navigation dan About. 


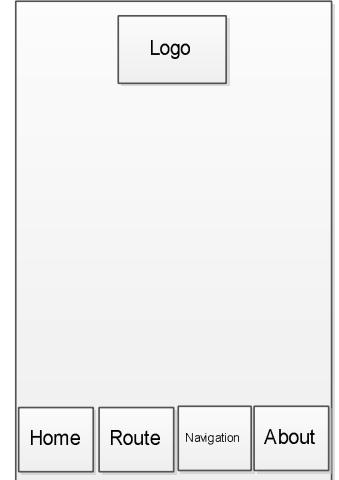

Gambar 3. 4 RANGCANGAN TAMPILAN HOME

\section{Rancangan Tampilan Route}

Pada menu route ini terdapat dua sub menu yaitu angkutan umum dan wisata.

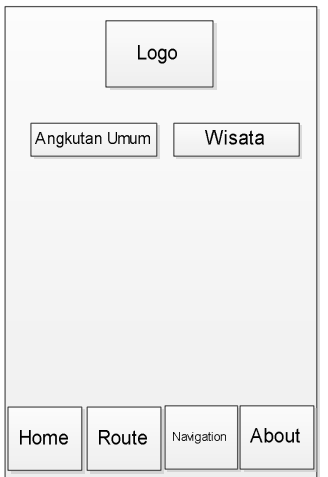

Gambar 3. 5 Rancangan TAMPILAN ROUTE

\section{Rancangan Tampilan Navigation}

Pada halaman navigation ini terdapat dua pilihan yaitu lokasi awal dan tujuan tempat wisata. Kemudian setelah memilih lokasi awal dan tujuan maka klik proses maka akan menampilkan rute angkutan umum. Didalam penjelasan rute angkutan umum tersebut terdapat link menuju rute yang akan ditempuh berupa map lokasi.

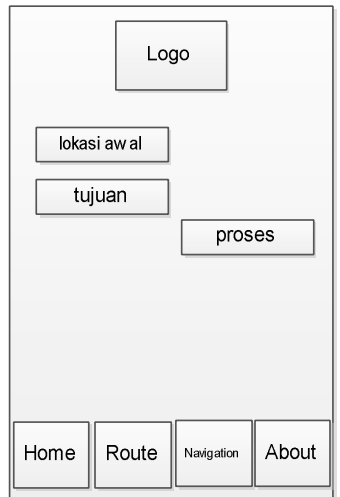

Gambar 3. 6 RanCANGAN TAMPILAN NAVIGATION

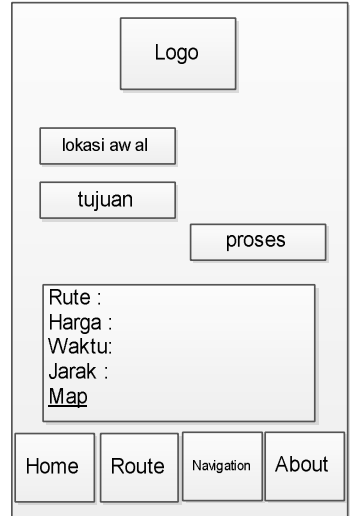

Gambar 3. 7 Rancangan Tampilan Setelah Proses

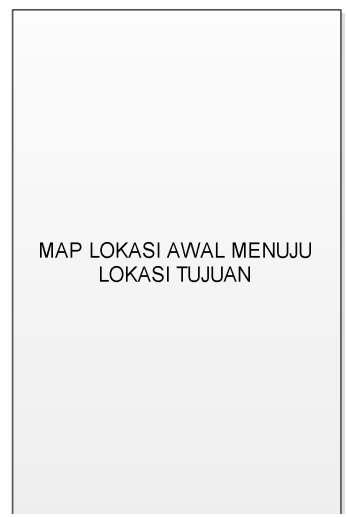

Gambar 3. 8 Rancangan TAMPILAN SETELAH KLIK MAP

4. Rancangan Tampilan About

Pada halaman about ini terdapat dua pilihan sub menu yaitu About Karanganyar dan About App.

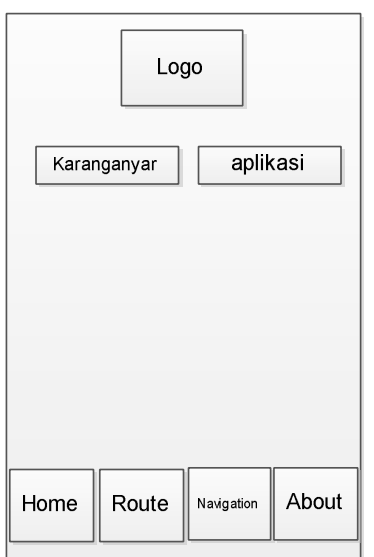

Gambar 3. 9 Rancangan Tampilan About

\section{Hasil Dan Pembahasan}

\subsection{Hasil Rancangan Aplikasi}

Aplikasi yang dibangun adalah aplikasi pencarian rute angkutan umum berbasis android dengan menggunakan phonegap. Aplikasi ini 
dirancang untuk memenuhi kebutuhan masyarakat akan informasi rute angkutan umum menuju tempat wisata Wilayah Kabupaten Karanganyar. Dalam aplikasi ini bukan hanya menampilkan informasi mengenai rute angkutan umum tetapi juga tarif tiap angkutan umum, jarak tempuh, waktu tempuh serta informasi mengenai trayek angkutan umum dan lokasi wisata angkutan umum. Dalam aplikasi ini, terdapat beberapa pilihan alternatif rute angkutan umum yang nantinya dapat dipilih oleh pengguna sesuai dengan keinginan masing-masing pengguna. Selain mempermudah para pengguna dalam pencarian rute angkutan umum menuju tempat wisata, aplikasi ini juga dapat memperkenalkan tempat-tempat wisata Wilayah Kabupaten Karanganyar kepada masyarakat. Resiko salah menaiki angkutan umum menuju lokasi wisata juga dapat dihindari dengan menggunakan aplikasi ini.

\subsubsection{Logo Aplikasi}

Logo aplikasi ini dirancang sebagai simbol atau lambang yang mewakili aplikasi pencarian rute angkutan umum ini. Berikut adalah tampilan logo yang telah penulis rancang.

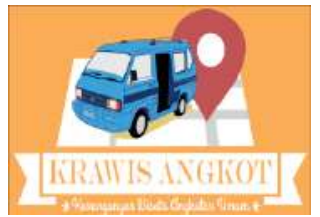

Gambar 4. 1 Logo Aplikasi KraWis ANGKot

\subsubsection{Tampilan Menu Home}

Tampilan Home ini adalah tampilan utama dari aplikasi Pencarian Rute Angkutan Umum Wisata berbasis Android. Pada menu Home ini terdapat menu-menu yang berada pada tampilan bawah yaitu menu Route, Navigation, dan About.

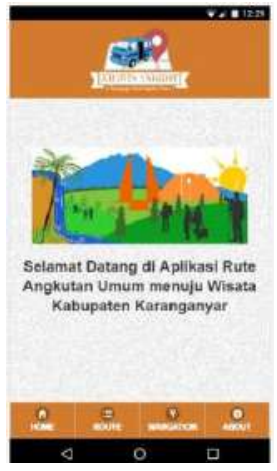

Gambar 4. 2 TAMPILAN HOME

\subsubsection{Tampilan Menu Route}

Menu Route ini menampilkan informasi mengenai trayek rute angkutan umum. Dalam menu ini terdapat dua pilihan sub menu yaitu Angkutan Umum dan Wisata. Angkutan umum berisi mengenai trayek angkutan umum Wilayah Kabupaten Karanganyar beserta tarifnya. Sedangkan sub menu wisata berisi pilihan lokasi tempat wisata Wilayah Kabupaten Karanganyar beserta penjelasan singkat mengenai wisata yang disertai dengan foto lokasi tersebut.

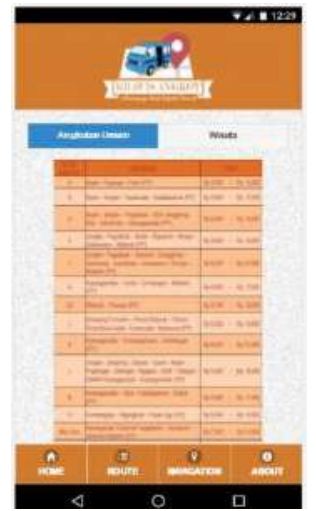

Gambar 4. 3 Tampilan Menu Route dan Sub Menu Angkutan Umum

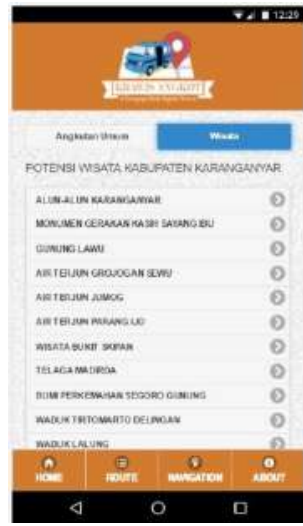

Gambar 4. 4 Tampilan Sub Menu Wisata

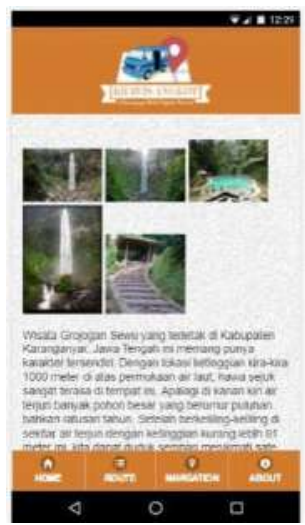

Gambar 4. 5 Tampilan Pilihan Wisata 


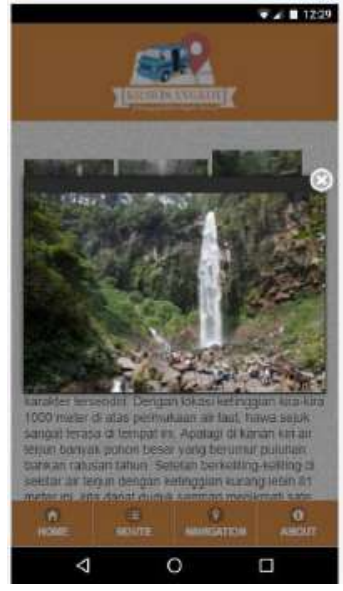

GaMBAR 4. 6 TAMPILAN FOTO LOKASI WISATA

\subsubsection{Tampilan Menu Navigation}

Menu navigation ini berisi pilihan lokasi awal dan tujuan kemudian pilihan tersebut diproses sehingga akan ditampilkan informasi rute angkutan umum yang disertai dengan tarif masing-masing angkutan umum yang dinaiki, jarak dan waktu tempuh menuju lokasi tujuan. Setiap pilihan rute angkutan umum terdapat link yang akan menghubungkan ke google map sesuai dengan lokasi awal dan tujuan yang telah diinputkan sebelumnya.

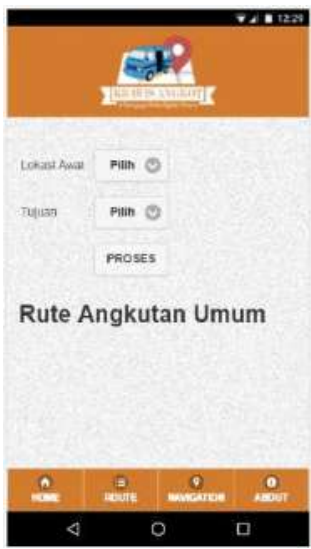

GAMBAR 4. 7 TAMPILAN NAVIGATION

Berikut adalah tampilan setelah pilihan lokasi awal dan tujuan dipilih kemudian klik tombol proses. Aplikasi akan menampilkan beberapa pilihan rute angkutan umum dengan jarak dan waktu tempuh disesuaikan dengan rute angkutan umum tersebut.

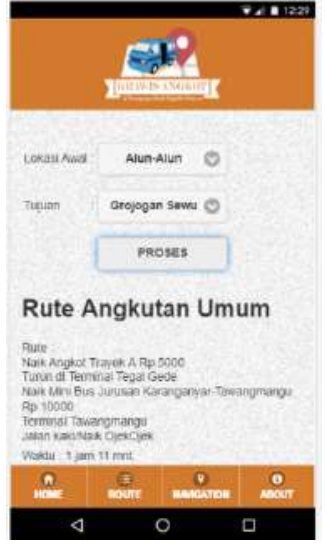

Gambar 4. 8 Tampilan Setelah Proses

Pada setiap pilihan rute angkutan umum yang ditampilkan masing-masing memiliki link "Go to Map" yang akan menampilkan rute angkutan sesuai dengan rute yang dipilih.
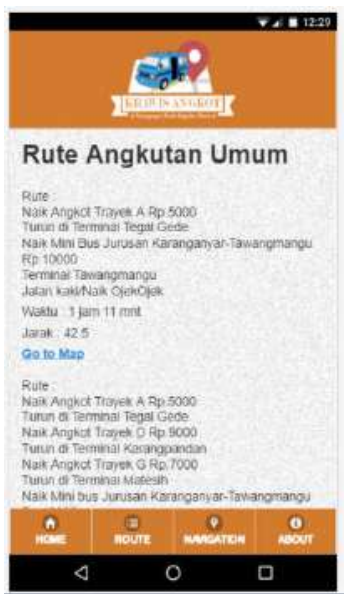

Gambar 4. 9 Tampilan Pilihan Satu Rute ANGKUTAN UMUM

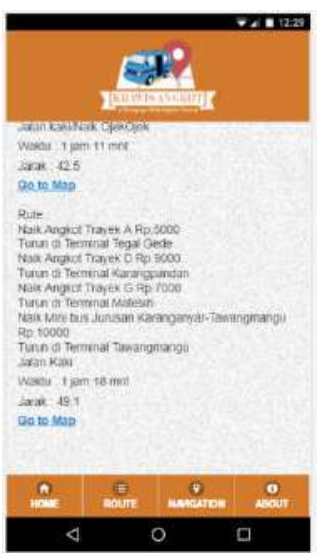

Gambar 4. 10 TAmPILAN PILIHAN DUA RUte ANGKUTAN UMUM 
Setelah klik "Go to Map" maka akan langsung tersambung pada google map dengan lokasi awal dan tujuan sesuai dengan yang dipilih sebelumnya serta sesuai dengan rute angkutan umum yang telah dipilih juga.

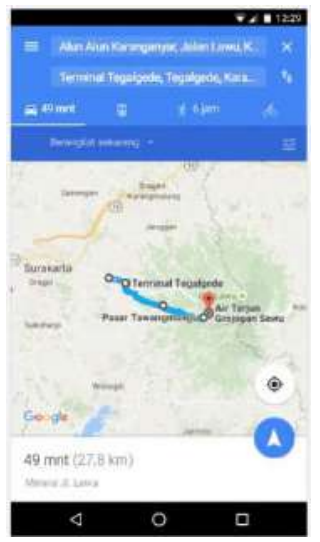

\section{Gambar 4. 11 TampILAN NAVIGaSI}

\subsubsection{Tampilan Menu About}

Menu About pada aplikasi ini berisi dua sub menu aplikasi yaitu About Karanganyar dan About App. About Karanganyar berisi penjelasan singkat mengenai Kabupaten Karanganyar sedangkan About App berisi mengenai penjelasan singkat meengenai aplikasi serta biodata mengenai pembuat aplikasi.

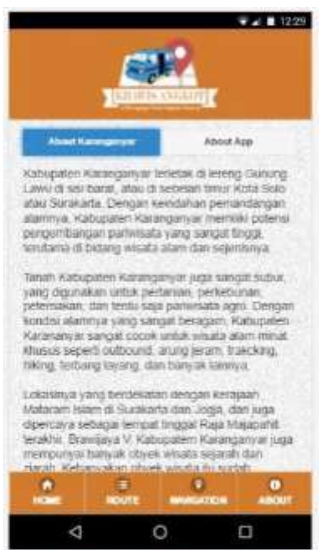

Gambar 4. 12 Tampilan About Karanganyar

Pada sub menu About App terdapat penjelasan singkat mengenai aplikasi. Pada sub menu ini juga terdapat tombol Developer yang jika di klik akan muncul popup mengenai biodata pembuat aplikasi.

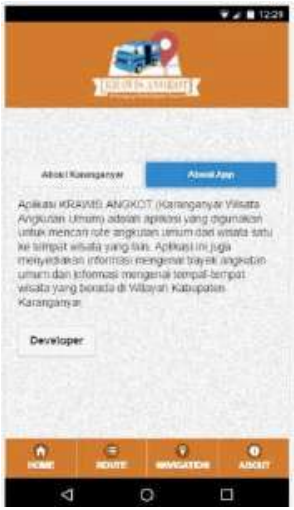

Gambar 4. 13 Tampilan About App

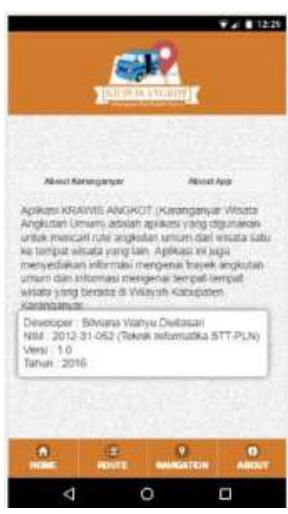

Gambar 4. 14 TAmpilan DeVELOPER

\subsection{Pembahasan}

Aplikasi pencarian rute angkutan umum ini dirancang untuk membantu para pangguna jasa angkutan umum dalam pencarian rute angkutan umum menuju lokasi wisata serta dapat mengurangi resiko salah menaiki angkutan umum. Aplikasi ini nantinya akan dapat digunakan oleh seluruh masyarakat pengguna jasa angkutan umum Wilayah Kabupaten Karanganyar. Aplikasi pencarian rute angkutan umum ini mempunyai menu untuk pencarian rute angkutan umum dari lokasi wisata satu ke lokasi wisata yang lain. Saat diproses, maka aplikasi ini akan menampilkan beberapa alternatif rute angkutan umum menuju lokasi tujuan.

Pilihan alternative rute angkutan tersebut akan diurutkan sesuai dengan jarak tempuh terpendek. Metode yang digunakan agar pilihan alternatif rute angkutan tersebut terurut adalah dengan menggunakan metode bubble sort. Metode bubble sort merupakan metode membandingkan dua data kemudian jika kondisi yang telah ditentukan benar maka data tersebut ditukar satu sama lain begitu seterusnya sehingga didapat pilihan alternative sesuai dengan jarak tempuh. Jarak tempuh yang dibandingkan ini merupakan total jarak tempuh dari lokasi wisata satu ke lokasi wisata yang lainnya berdasarkan rute angkutan umum sekaligus dengan jarak transit angkutan umum satu ke angkutan umum yang lainnya. Total jarak tempuh tersebut kemudian dibandingkan sehingga menghasilkan 
urutan rute angkutan umum terpendek berdasarkan jaraknya. Aplikasi ini dapat memberikan pilihan rute angkutan umum sehingga pengguna nantinya akan dapat memilih rute angkutan umum sesuai dengan keinginan masing-masing.

\subsubsection{Pembahasan Metode}

Pada aplikasi pencarian rute angkutan umum ini terdapat proses yang menggunakan metode buble sort. Metode ini digunakan untuk mencari rute angkutan umum dengan jarak tempuh terpendek dari beberapa pilihan rute angkutan umum yang tersedia.

Tahap metode buble sort adalah sebagai berikut :

1. Menentukan data-data yang akan dibandingkan

2. Membandingkan data yang telah ditentukan, jika data1 lebih besar dibandingkan data2 maka data akan ditukar

3. Selanjutnya langkah yang sama sampai data yang dibandingkan terurut

Berikut kode buble sort yang digunakan dalam pembuatan aplikasi rute angkutan umum.

var swapped;

do \{

swapped $=$ false

for (var $\mathrm{i}=0 ; \mathrm{i}<$ jrute $-1 ; \mathrm{i}++)\{$

if $(\operatorname{Jarak}[i]>\operatorname{Jarak}[i+1])\{$

var temp = Jarak[i];

$\operatorname{Jarak}[i]=\operatorname{Jarak}[i+1]$

$\operatorname{Jarak}[i+1]=$ temp;

var temp1 = Rute[i];

Rute $[i]=$ Rute $[i+1]$

Rute $[i+1]=$ temp 1 ;

var temp2 $=$ Menit[i]

Menit[i] $=$ Menit $[i+1]$

Menit $[i+1]=$ temp2;

var temp3 $=$ Web[i];

$\mathrm{Web}[\mathrm{i}]=\mathrm{Web}[\mathrm{i}+1]$;

Web $[i+1]=$ temp3;

\}

swapped = true;

\}

\} while (swapped);

Berikut adalah penjelasan penggunaan koding buble sort secara manual. Misalnya pilihan lokasi awal adalah Alun-Alun dan lokasi tujuan adalah Air Terjun Jumog.

- Pilih1 = Alun-Alun

- Pilih2 = Air Terjun Jumog

Jrute $=3$

$\mathrm{i}=0$ to $\mathrm{i}<2$

$\mathrm{i}=0$

jarak[0]>jarak[1] $=28.9>35.7$ (salah)

next i

$i=1$

jarak [1] > jarak [2] = $35.7>35.1$ (benar)

temp $=$ jarak[1] $\quad \rightarrow$ temp $=35.7$

$\operatorname{jarak}[1]=\operatorname{jarak}[2] \quad \rightarrow \operatorname{jarak}[1]=35.1$

jarak[2] = temp $\rightarrow$ jarak[2] $=35.7$ temp1 $=$ rute[1] $\rightarrow$ temp1 $=$

Naik Angkot Trayek A:5000

Turun di Terminal Tegal Gede

Naik Angkot Trayek E:6000

Turun di Matesih

Naik Angkot Trayek G:7000

Turun di Karangpandan

Naik Mini Bus Jurusan Karangpandan-Kemuning-

Kerjo

Turun di Kemuning:10000

Jalan Kaki/ Naik Ojek

rute[1] $=$ rute[2] $\rightarrow$ rute[1]

= Naik Mini Bus Jurusan Karanganyar-

Matesih-Tawangmangu:10000

Turun di Terminal Matesih

Naik Angkot Trayek G:7000

Turun di Karangpandan

Naik Mini Bus Jurusan Karangpandan-KemuningKerjo:10000

Turun di Kemuning

Jalan Kaki/Naik Ojek

rute[2] = temp1 $\rightarrow$ rute[2]

$=$ Naik Angkot Trayek A:5000

Turun di Terminal Tegal Gede

Naik Angkot Trayek E:6000

Turun di Matesih

Naik Angkot Trayek G:7000

Turun di Karangpandan

Naik Mini Bus Jurusan Karangpandan-KemuningKerjo

Turun di Kemuning:10000

Jalan Kaki/ Naik Ojek

Temp2 $=$ menit[1] $\rightarrow$ temp3 = 1 jam 15 menit

Menit[1] = menit[2] $\rightarrow$ menit[1] $=1$ jam 13 menit

Menit[2] $=$ temp2 $\rightarrow$ menit[2] $=1$ jam 15 menit

Temp3 $=$ web[1]

Web[1] $=$ web[2]

Web[2] = temp3

END

Jadi, hasil yang diperoleh adalah sebagai berikut :

- Pilihan 1

Rute[0] : Naik Angkot Trayek A:5000

Turun di Terminal Tegal Gede

Naik Angkot Trayek D:9000

Turun di Terminal Karangpandan

Naik Mini Bus Jurusan Karangpandan-

Kemuning-Kerjo: 10000

Turun di Terminal Kemuning

Jalan Kaki/Naik Ojek

Menit[0] : 1 jam

Jarak[0] : 28.9

Web[0]

- Pilihan 2

Rute[1] : Naik Mini Bus Jurusan Karanganyar-

Matesih-Tawangmangu:10000

Turun di Terminal Matesih

Naik Angkot Trayek G:7000

Turun di Karangpandan

Naik Mini Bus Jurusan Karangpandan-

Kemuning-Kerjo:10000

Turun di Kemuning

Jalan Kaki/Naik Ojek

Menit[1] : 1 jam 13 menit 
Jarak[1] : 35.1

Web[1]

- Pilihan 3

Rute[2] : Naik Angkot Trayek A:5000

Turun di Terminal Tegal Gede

Naik Angkot Trayek E:6000

Turun di Matesih

Naik Angkot Trayek G:7000

Turun di Karangpandan

Naik Mini Bus Jurusan Karangpandan-

Kemuning-Kerjo

Turun di Kemuning:10000

Jalan Kaki/ Naik Ojek

Menit[2] : 1 jam 15 menit

Jarak[2] : 35.7

Web[2]

\subsection{Pengujian Sistem}

\subsubsection{Black Box}

Pada skenario pengujian ini, penulis menggunakan metode black box testing. Pengujian ini bertujuan untuk menunjukkan fungsi dari perangkat lunak mengenai jalannya aplikasi yang dibuat apakah hasilnya telah berjalan sebagaimana yang diharapkan dalam perancangan.

Berikut merupakan hasil dari pengujian dengan menggunakan metode black box testing.

Tabel 4. 1 Hasil Pengujian Black BoX

\begin{tabular}{|c|c|c|c|c|}
\hline No & $\begin{array}{c}\text { Antarmuka } \\
\text { yang diuji }\end{array}$ & $\begin{array}{l}\text { Bagian dari } \\
\text { antarmuka } \\
\text { yang diuji }\end{array}$ & $\begin{array}{l}\text { Skenario } \\
\text { Pengujian }\end{array}$ & $\begin{array}{c}\text { Hasil } \\
\text { Pengujian }\end{array}$ \\
\hline 1 & Menu Home & $\begin{array}{l}\text { Tombol } \\
\text { Home }\end{array}$ & $\begin{array}{l}\text { Ketika ditekan } \\
\text { tombol Home } \\
\text { maka akan } \\
\text { menuju tampilan } \\
\text { utama }\end{array}$ & Berhasil \\
\hline \multirow[t]{3}{*}{2} & \multirow[t]{3}{*}{ Menu Route } & $\begin{array}{l}\text { Sub Menu } \\
\text { Angkutan } \\
\text { Umum }\end{array}$ & $\begin{array}{l}\text { Ketika sub menu } \\
\text { Angkutan umum } \\
\text { ditekan, maka } \\
\text { muncul daftar } \\
\text { trayek angkutan } \\
\text { umum }\end{array}$ & Berhasil \\
\hline & & $\begin{array}{l}\text { Sub Menu } \\
\text { Wisata }\end{array}$ & $\begin{array}{l}\text { Ketika sub menu } \\
\text { Wisata ditekan } \\
\text { maka akan } \\
\text { muncul pilihan } \\
\text { tempat wisata }\end{array}$ & Berhasil \\
\hline & & $\begin{array}{l}\text { Pilihan } \\
\text { Tempat } \\
\text { Wlsata }\end{array}$ & $\begin{array}{l}\text { Ketika memilih } \\
\text { salah satu } \\
\text { tempat wisata } \\
\text { maka akan } \\
\text { muncul } \\
\text { penjelasan } \\
\text { singkat } \\
\text { mengenai } \\
\text { tempat wisata } \\
\text { beserta } \\
\text { gambarnya }\end{array}$ & Berhasil \\
\hline \multirow[t]{2}{*}{3} & \multirow[t]{2}{*}{$\begin{array}{l}\text { Menu } \\
\text { Navigation }\end{array}$} & $\begin{array}{l}\text { Tombol } \\
\text { Proses }\end{array}$ & $\begin{array}{l}\text { Ketika tombol } \\
\text { proses ditekan } \\
\text { maka akan } \\
\text { muncul rute } \\
\text { angkutan umum, } \\
\text { harga, waktu } \\
\text { dan jarak serta } \\
\text { link Go to Map }\end{array}$ & Berhasil \\
\hline & & $\begin{array}{l}\text { Tombol Go } \\
\text { To Map }\end{array}$ & $\begin{array}{l}\text { Ketika tombol } \\
\text { Go to Map } \\
\text { ditekan maka } \\
\text { akan langsung } \\
\text { menuju Map } \\
\text { sesuai dengan } \\
\text { pilihan lokasi } \\
\text { awal dan tujuan }\end{array}$ & Berhasil \\
\hline 4 & Menu About & $\begin{array}{l}\text { Sub Menu } \\
\text { About } \\
\text { Karanganyar }\end{array}$ & $\begin{array}{l}\text { Ketika sub menu } \\
\text { About } \\
\text { Karanganyar } \\
\text { ditekan maka } \\
\text { akan muncul } \\
\text { penjelasan }\end{array}$ & Berhasil \\
\hline
\end{tabular}

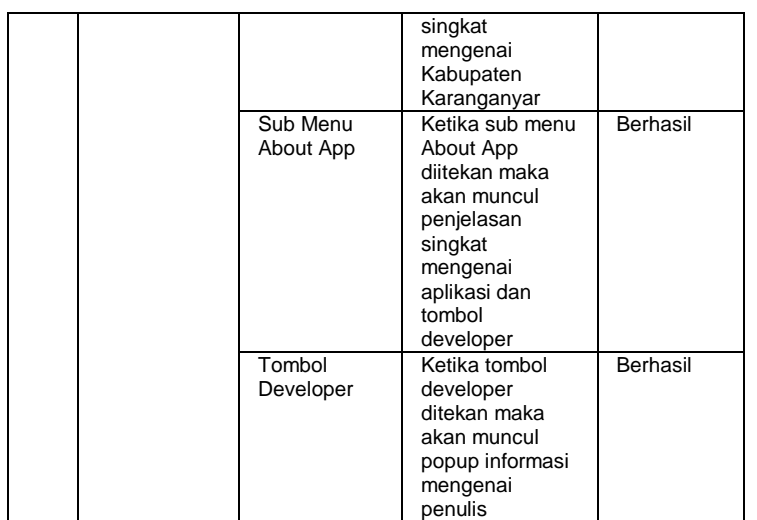

Dari hasil pengujian black box tersebut, dapat ditarik kesimpulan bahwa aplikasi rute pencarian angkutan umum tersebut dibuat sesuai dengan rancangan aplikasi dan fungsi-fungsi serta proses yang terdapat pada aplikasi berjalan dengan baik.

\subsubsection{Kuesioner}

Pengujian merupakan bagian yang penting dalam siklus perangkat lunak. Tujuan dari pengujian adalah untuk menjamin perangkat lunak yang dibangun sesuai dengan yang diharapkan dan dirancang sebelumnya.

Pengujian kelayakan aplikasi ini dilakukan dengan membagiakan kuesioner kepada 10 responden. Hasil dari kuesioner tersebut akan ditunjukkan dalam bentuk table sebagai berikut :

\section{Pertanyaan No 1}

TABel 4. 2 Penilaian PERTANyAan No 1

\begin{tabular}{|c|c|c|c|}
\hline Pertanyaan & $\begin{array}{c}\text { Pilihan } \\
\text { Jawaban }\end{array}$ & $\begin{array}{c}\text { Jumlah } \\
\text { Responden }\end{array}$ & Presentase \\
\hline \multirow{4}{*}{$\begin{array}{c}\text { Aplikasi ini } \\
\text { mudah } \\
\text { digunakan? }\end{array}$} & $\begin{array}{c}\text { Sangat } \\
\text { Setuju }\end{array}$ & 10 & $100 \%$ \\
\cline { 2 - 4 } & Setuju & 0 & $0 \%$ \\
\cline { 2 - 4 } & $\begin{array}{c}\text { Kurang } \\
\text { Setuju }\end{array}$ & 0 & $0 \%$ \\
\cline { 2 - 4 } & $\begin{array}{c}\text { Tidak } \\
\text { Setuju }\end{array}$ & 0 & $0 \%$ \\
\hline
\end{tabular}

2. Pertanyaan No 2

Tabel 4. 3 Penilaian pertanyaan No 2

\begin{tabular}{|c|c|c|c|}
\hline Pertanyaan & $\begin{array}{l}\text { Pilihan } \\
\text { Jawaban }\end{array}$ & $\begin{array}{c}\text { Jumlah } \\
\text { Responden }\end{array}$ & Presentase \\
\hline \multirow{4}{*}{$\begin{array}{l}\text { Semua fungsi } \\
\text { berjalan } \\
\text { dengan baik? }\end{array}$} & $\begin{array}{l}\text { Sangat } \\
\text { Setuju }\end{array}$ & 10 & $100 \%$ \\
\hline & Setuju & 0 & $0 \%$ \\
\hline & $\begin{array}{l}\text { Kurang } \\
\text { Setuju }\end{array}$ & 0 & $0 \%$ \\
\hline & $\begin{array}{l}\text { Tidak } \\
\text { Setuju }\end{array}$ & 0 & $0 \%$ \\
\hline
\end{tabular}

3. Pertanyaan No 3 
TABEL 4. 4 PENILAIAN PERTANYAAN No 3

\begin{tabular}{|c|c|c|c|}
\hline Pertanyaan & $\begin{array}{c}\text { Pilihan } \\
\text { Jawaban }\end{array}$ & $\begin{array}{c}\text { Jumlah } \\
\text { Responden }\end{array}$ & Presentase \\
\hline \multirow{4}{*}{$\begin{array}{c}\text { aplikasi ini dapat } \\
\text { memberikan } \\
\text { informasi? }\end{array}$} & $\begin{array}{c}\text { Sangat } \\
\text { Setuju }\end{array}$ & 9 & $90 \%$ \\
\cline { 2 - 4 } & Setuju & 1 & $10 \%$ \\
\cline { 2 - 4 } & $\begin{array}{c}\text { Kurang } \\
\text { Setuju }\end{array}$ & 0 & $0 \%$ \\
\cline { 2 - 4 } & $\begin{array}{c}\text { Tidak } \\
\text { Setuju }\end{array}$ & 0 & $0 \%$ \\
\hline
\end{tabular}

4. Pertanyaan No 4

Tabel 4. 5 Penilaian PERTANyaAn No 4

\begin{tabular}{|c|c|c|c|}
\hline Pertanyaan & $\begin{array}{c}\text { Pilihan } \\
\text { Jawaban }\end{array}$ & $\begin{array}{c}\text { Jumlah } \\
\text { Responden }\end{array}$ & Presentase \\
\hline \multirow{2}{*}{$\begin{array}{c}\text { informasi yang } \\
\text { ditampilkan jelas } \\
\text { dan lengkap? }\end{array}$} & $\begin{array}{c}\text { Sangat } \\
\text { Setuju }\end{array}$ & 10 & $100 \%$ \\
\cline { 2 - 4 } & $\begin{array}{c}\text { Setuju } \\
\text { Kurang } \\
\text { Setuju }\end{array}$ & 0 & $0 \%$ \\
\cline { 2 - 4 } & $\begin{array}{c}\text { Tidak } \\
\text { Setuju }\end{array}$ & 0 & $0 \%$ \\
\hline
\end{tabular}

\section{Pertanyaan No 5}

TABel 4. 6 Penilaian PERTANyAan No 5

\begin{tabular}{|c|c|c|c|}
\hline Pertanyaan & $\begin{array}{l}\text { Pilihan } \\
\text { Jawaban }\end{array}$ & $\begin{array}{l}\text { Jumlah } \\
\text { Responden }\end{array}$ & Presentase \\
\hline \multirow{4}{*}{$\begin{array}{l}\text { Informasi yang } \\
\text { diberikan } \\
\text { bermanfaat untuk } \\
\text { pengguna? }\end{array}$} & $\begin{array}{l}\text { Sangat } \\
\text { Setuju }\end{array}$ & 10 & $100 \%$ \\
\hline & Setuju & 0 & $0 \%$ \\
\hline & $\begin{array}{l}\text { Kurang } \\
\text { Setuju }\end{array}$ & 0 & $0 \%$ \\
\hline & $\begin{array}{l}\text { Tidak } \\
\text { Setuju }\end{array}$ & 0 & $0 \%$ \\
\hline
\end{tabular}

\section{Pertanyaan No 6}

TABel 4. 7 Penilaian PERTANyAan No 6

\begin{tabular}{|c|c|c|c|}
\hline \multirow{2}{*}{ Pertanyaan } & $\begin{array}{c}\text { Pilinan } \\
\text { Jawaban }\end{array}$ & $\begin{array}{c}\text { Jumlah } \\
\text { Responden }\end{array}$ & Presentase \\
\hline \multirow{2}{*}{$\begin{array}{c}\text { aplikasi membantu } \\
\text { pengguna dalam } \\
\text { mencari rute } \\
\text { angkutan umum }\end{array}$} & $\begin{array}{c}\text { Sangat } \\
\text { Setuju }\end{array}$ & 10 & $100 \%$ \\
\cline { 2 - 4 } & $\begin{array}{c}\text { Setuju } \\
\text { Setuju }\end{array}$ & 0 & $0 \%$ \\
\cline { 2 - 4 } & $\begin{array}{c}\text { Tidak } \\
\text { Setuju }\end{array}$ & 0 & $0 \%$ \\
\hline
\end{tabular}

\section{Pertanyaan No 7}

TABel 4. 8 Penila AIAN PERTANyAan No 7

\begin{tabular}{|c|c|c|c|}
\hline Pertanyaan & $\begin{array}{c}\text { Pilihan } \\
\text { Jawaban }\end{array}$ & $\begin{array}{c}\text { Jumlah } \\
\text { Responden }\end{array}$ & Presentase \\
\hline \multirow{2}{*}{$\begin{array}{c}\text { aplikasi ini } \\
\text { memberikan } \\
\text { informasi } \\
\text { mengenai tempat } \\
\text { wisata }\end{array}$} & $\begin{array}{c}\text { Sangat } \\
\text { Setuju }\end{array}$ & 10 & $100 \%$ \\
\cline { 2 - 4 } & $\begin{array}{c}\text { Setuju } \\
\text { Kurang } \\
\text { Setuju }\end{array}$ & 0 & $0 \%$ \\
\cline { 2 - 4 } & $\begin{array}{c}\text { Tidak } \\
\text { Setuju }\end{array}$ & 0 & $0 \%$ \\
\hline
\end{tabular}

\section{Pertanyaan No 8}

TABel 4. 9 PENILAIAN PERTANYAAN No 8

\begin{tabular}{|c|c|c|c|}
\hline Pertanyaan & $\begin{array}{l}\text { Pilihan } \\
\text { Jawaban }\end{array}$ & $\begin{array}{l}\text { Jumlah } \\
\text { Responden }\end{array}$ & Presentase \\
\hline \multirow{4}{*}{$\begin{array}{l}\text { tampilan } \\
\text { menarik? }\end{array}$} & $\begin{array}{l}\text { Sangat } \\
\text { Setuju }\end{array}$ & 9 & $90 \%$ \\
\hline & Setuju & 1 & $10 \%$ \\
\hline & $\begin{array}{c}\text { Kurang } \\
\text { Setuju }\end{array}$ & 0 & $0 \%$ \\
\hline & $\begin{array}{l}\text { Tidak } \\
\text { Setuju }\end{array}$ & 0 & $0 \%$ \\
\hline
\end{tabular}

\section{Pertanyaan No 9}

Tabel 4. 10 Penilaian pertanyaAn No 9

\begin{tabular}{|c|c|c|c|}
\hline Pertanyaan & $\begin{array}{l}\text { Pilihan } \\
\text { Jawaban }\end{array}$ & $\begin{array}{c}\text { Jumlah } \\
\text { Responden }\end{array}$ & Presentase \\
\hline \multirow{4}{*}{$\begin{array}{l}\text { aplikasi ini } \\
\text { sesuai dengan } \\
\text { harapan } \\
\text { pengguna? }\end{array}$} & $\begin{array}{l}\text { Sangat } \\
\text { Setuju }\end{array}$ & 10 & $100 \%$ \\
\hline & Setuju & 0 & $0 \%$ \\
\hline & $\begin{array}{l}\text { Kurang } \\
\text { Setuju }\end{array}$ & 0 & $0 \%$ \\
\hline & $\begin{array}{l}\text { Tidak } \\
\text { Setuju }\end{array}$ & 0 & $0 \%$ \\
\hline
\end{tabular}

\section{Pertanyaan No 10}

TABEl 4. 11 PENILAIAN PERTANyAAN No 10

\begin{tabular}{|c|c|c|c|}
\hline Pertanyaan & $\begin{array}{l}\text { Pilihan } \\
\text { Jawaban }\end{array}$ & $\begin{array}{c}\text { Jumlah } \\
\text { Responden }\end{array}$ & Presentase \\
\hline \multirow{4}{*}{$\begin{array}{l}\text { aplikasi ini } \\
\text { layak untuk } \\
\text { dipublikasikan } \\
\text { sebagai media } \\
\text { informasi? }\end{array}$} & $\begin{array}{l}\text { Sangat } \\
\text { Setuju }\end{array}$ & 8 & $80 \%$ \\
\hline & Setuju & 2 & $20 \%$ \\
\hline & $\begin{array}{l}\text { Kurang } \\
\text { Setuju }\end{array}$ & 0 & $0 \%$ \\
\hline & $\begin{array}{l}\text { Tidak } \\
\text { Setuju }\end{array}$ & 0 & $0 \%$ \\
\hline
\end{tabular}

Dari hasil kuesioner yang telah dibagikan kepada 10 responden, didapat kesimpulan bahwa aplikasi pencarian rute angkutan umum wisata berbasis android ini berjalan dengan baik tanpa adanya error dan menghasilkan tampilan menarik, mudah digunakan dan membantu serta dibutuhkan oleh para konsumen saat menggunakan jasa angkutan umum menuju lokasi wisata Wilayah Kabupaten Karanganyar.

\section{Penutup}

5.1. Kesimpulan

Dari hasil penelitian yang dilakukan dari tahap pengkonsepan hingga tahap pengujian, dapat disimpulkan bahwa :

1. Aplikasi ini dapat membantu memberikan informasi mangenai tempat-tempat wisata sehingga mempermudah pengguna dalam penentuan tujuan lokasi wisata dan juga dapat memperkenalkan lokasi-lokasi wisata Wilayah Kabupaten Karanganyar. 
2. Aplikasi ini dapat membantu para pengguna dalam pencarian rute angkutan umum beserta tarif masing-masing trayek angkutan umum dari lokasi wisata satu kelokasi wisata yang lain pada wilayah Kabupaten Karanganyar.

3. Aplikasi ini sudah dalam bentuk .apk sehingga dapat diinstall pada smartphone berbasis android.

4. Aplikasi ini dapat memberikan beberapa pilihan rute yang dapat ditempuh untuk mencapai lokasi wisata Wilayah Kabupaten Karanganyar sehingga pengguna dapat memilih rute sesuai dengan keinginan masingmasing.

5. Aplikasi ini dapat mengurangi resiko salah menaiki angkutan umum dengan rute yang berbeda dari tujuannya.

\subsection{Saran}

Berdasarkan hasil penelitian, peneliti memberikan saran sebagai berikut :

1. Aplikasi ini baru berjalan di smartphone android saja. Untuk pengembangan selanjutnya diharapkan dapat dibangun aplikasi lintas platform seperti IOS, Blackberry 10, Windows Phone

2. Pengembangan aplikasi ini diharapkan mampu memberikan data yang mudah diupdate sewaktu-waktu oleh pihak-pihak yang terkait.

3. Aplikasi ini memiliki fitur ubah bahasa yang digunakan

4. Aplikasi ini dapat memberikan notifikasi ketika sampai pada lokasi tujuan

\section{DAFTAR PUSTAKA}

1. Andilolo, d. (2014). Perancangan dan Pembuatan Aplikasi Informasi Transportasi Umum DI Surabaya Berbasis Android.

2. Dodo, S. (2012). Proposal Skripsi Pembuatan Aplikasi Informasi Lokasi Perguruan Tinggi DI Yogyakarta Berbasis Web GIS. Fakultas Teknologi Industri Institut Sains \& Teknologi Akprid Yogyakarta.

3. Dudung. (2014). Pengertian komponen dan fungsi xampp. Retrieved from http://www.dosenpendidikan.com/pengertiankomponen-dan-fungsi-xampp-lengkapdengan-penjelasannya/.

4. Gumelar, C. (2015). Sistem Informasi Transportasi Di Palembang Berbasis Android pada PT. Sarana Pembangunan Palembang Jaya. Jurusan Sistem Informasi STMIK GI MDP : Palembang.

5. Luis. (2016). Definisi dan Apakah itu Phonegap. Retrieved from http://www.matawebsite.com/definisi-danapakah-itu-phonegap.
6. Mustofa. (2012). Nodejs. Retrieved from http://bisakomputer.com/nodejs-membangunwebsite-dengan-express-framework/.

7. Nazzrudin, S. (2013). Android- Pemrograman Alikasi Mobile Smartphone dan Tablet PC Berbasis Android. Bandung : Informatika.

8. Sigi, A. L. (2015). Perancangan Aplikasi Sarana Dan Rumah Tangga Laboratorium Komputer Teknik Informatika STT-PLN. Teknik Informatika STT-PLN.

9. Triyudanto, A. (2012). Pengertian Backpacker. Retrieved from http://www.backpackerindonesia.com/blogs/ amrizal-triyudanto/pengertian-backpacker.

10. Warpani. (1990). Retrieved from http://repository.usu.ac.id/bitstream/12345678 9/20468/3/Chapter\%20II.pdf.

11. Webhozz. (2015). Android Developeer. Jakarta: Webhozz.

12. Winanda, L. J. (2014). Perancangan Aplikasi Rute Angkutan Umum Di Kota Tangerang Selatan Berbasis Smartphone. Teknik Informatika Fakultas Sains dan Teknologi Universitas Islam Negeri Syarif Hidayatullah.

13. Yogaswara, A. (2013). Membangun Aplikasi Trayek Angkutan Kota Di Bandung Berbasis Android. Bandung : UNIKOM Bandung. 